\title{
Methylated DNA/RNA in Body Fluids as Biomarkers for Lung Cancer
}

\author{
Yan Lu', Shulin/SL Li $i^{2}$, Shiguo/SG Zhu' ${ }^{3}$, Yabin/YB Gong ${ }^{1}$, Jun/J Shi ${ }^{1}$ and Ling/ L Xu'
}

\begin{abstract}
DNA/RNA methylation plays an important role in lung cancer initiation and progression. Liquid biopsy makes use of cells, nucleotides and proteins released from tumor cells into body fluids to help with cancer diagnosis and prognosis. Methylation of circulating tumor DNA (ctDNA) has gained increasing attention as biomarkers for lung cancer. Here we briefly introduce the biological basis and detection method of ctDNA methylation, and review various applications of methylated DNA in body fluids in lung cancer screening, diagnosis, prognosis, monitoring and treatment prediction. We also discuss the emerging role of RNA methylation as biomarkers for cancer.
\end{abstract}

Keywords: Lung cancer, Liquid biopsy, ctDNA, Circulating RNA, Methylation

\section{Background}

Lung Cancer is the second most common malignant tumor and the leading cause of cancer deaths worldwide [1]. Smoking tobacco is the primary risk factor for lung cancer $[1,2]$. Early detection and surgery offer the best chance for survival. Screening using low-dose computed tomography (LDCT) has been proved to improve early detection and reduce mortality [3]. However, LDCT is far from satisfactory as a screen tool due to its low specificity [4]. And $30 \%$ of patients with as early as stage I lung cancer experience relapse after surgery and recommended adjuvant chemotherapy [5], and for advanced and metastatic disease that is inoperable, patients have to receive radiotherapy, chemotherapy, targeted therapy and immunotherapy and experience remission, recurrence and metastasis. Surveillance plan and treatment decisions are conventionally made based on group statistics and not precise or personalized. The overall 5 year survival of lung cancer is only $17.7 \%$ [6]. Therefore, effective biomarkers for early detection, diagnosis, prognosis and monitoring of lung cancer are in urgent need.

Lung cancer is characterized by diverse genetic alterations, making the development of reliable and feasible DNA-based biomarkers very challenging. Epigenetic changes, referred to changes in gene regulation that are

\footnotetext{
* Correspondence: xulq67@aliyun.com

${ }^{1}$ No.2 oncology department, Yueyang Hospital of Integrated Traditional Chinese and Western Medicine, Shanghai University of Traditional Chinese Medicine, No.110, Ganhe Rd, Shanghai, China

Full list of author information is available at the end of the article
}

not attributed to changes in DNA sequence [7], are relatively consistent in carcinogenesis. Epigenetic abnormalities, comprising alterations in DNA/RNA methylation, histone modifications, nucleosome positioning and noncoding RNAs, are considered hallmarks of cancer initiation and progression [8]. Recent advances in the field of lung cancer epigenetics have revealed promising biomarkers, particularly involving ctDNA methylation and an emerging role of RNA methylation.

\section{DNA Hypermethylation and Hypomethylation in Lung Cancer Hypermethylation}

DNA methylation occurs at carbon-5 position of cytosine within $\mathrm{CpG}$ dinucleotides that scattered in human genome. The vast majority of the genome contains few CpGs, and most of them are methylated in normal cells. In contrast, around $2 \%$ of the genome contains high density of CpG in regions named CpG islands (CGIs) [9] that locate in $50-60 \%$ of gene promoters and are often unmethylated during normal development and in adult cells [10]. Methylated CGIs is generally a repressive mark of transcription initiation [11] that hinders the binding of activating transcriptional factors to DNA sequences [12,13] and recruits inhibitory proteins [14, 15]. The cancer genome is globally hypomethylated, except for the dense methylation at CGIs that is associated with the permanent repression of tumor suppressor genes and other cancer-related genes, thus promotes 
cancer progression $[11,16]$. In non-small cell lung cancer (NSCLC), CGI hypermethylation is associated with diagnosis [17, 18], staging [19], cigarette smoking [20], histological subtype [19, 21, 22], molecular subtypes [23-25], progression [26], prognosis [27-30], and used as a potential therapeutic target [31].

\section{Hypomethylation}

DNA hypomethylation $(\mathrm{m} 5 \mathrm{C}$ residues replaced by unmethylated $\mathrm{C}$ residues) is the initial epigenetic abnormality recognized in human tumors but has been ignored for a long time [32]. DNA methylation in repetitive sequences could be essential to maintain chromosomal integrity. Studies confirm that DNA hypomethylation is the most constant companion to hypermethylation of the genome in cancer [33-35], lung cancer included [36]. DNA hypomethylation in repetitive sequence occurred in early stage of squamous cell lung cancer [33], and individuals with hypomethylation in repetitive element are at a high risk of developing and dying from cancer [34]. Therefore, hypomethylation could be used as a screening, diagnosis and prognosis biomarker.

\section{Circulating Tumor DNA (ctDNA) Methylation Biological Basis of ctDNA}

Circulating cell-free DNA (cfDNA) is a mixture of single or double-stranded DNA in circulation released from different tissues including tumor. Since it is difficult to separate ctDNA from cfDNA originated from non-cancer tissues, careful selection of control group and target genes in a clinical trial is critical. As a result of nuclease digestion during the release processes, cfDNA are usually short fragments with generally very low concentration $[37,38]$. In cancer patients, level of cfDNA is elevated with ctDNA as a substantial fraction ranging from $<0.05$ [39] to $90 \%$ [40], depending on tumor volume, localization, vascularization, hepatic and renal clearance [41]. ctDNA mostly results from apoptosis and necrosis of primary and metastatic tumor [40]. Recent studies have also reported other sources of ctDNA, such as circulating tumor cells (CTCs) $[42,43]$, and exosomes released by tumor cells [44]. The concordant epigenetic alterations between ctDNA and corresponding tumor tissue DNA [45-48] make ctDNA methylation a promising biomarker for cancer diagnosis and prognosis. Other sources of methylated DNA from liquid biopsy have also been reported, such as cell-surfacebound circulating DNA (csbDNA) [49, 50], Buffy coat DNA [51], peripheral lymphocyte DNA [52,53], peripheral leukocyte DNA $[54,55]$, sputum [56] and exhaled breath condensate (EBC) [57].

\section{ctDNA Extraction Method}

cfDNA can be isolated from both plasma and serum. Although cfDNA from serum has been reported with higher quantity [58], its separation process is more demanding to prevent DNA released from the lysis of blood cells [37]. Anyway, it is essential to prepare DNA using very fresh serum/plasma. Therefore, it is highly recommended to process blood sample and separate DNA as soon as possible (within $4 \mathrm{~h}$ for serum and $8 \mathrm{~h}$ for plasma) [38]. The volume of blood sample necessary to obtain sufficient cfDNA depends on the downstream analysis method. Classical DNA purification methods used for tissues are not suitable for ctDNA [59], and lots of extraction kits designed for cfDNA have become available [59-61].

\section{ctDNA Methylation Detection Method}

Detection of ctDNA methylation has evolved from a few candidate genes to thousands of $\mathrm{CpG}$ sites, and recently to whole genome methylation analysis. Detection method of ctDNA methylation can be divided into three groups according to basic principles: sodium bisulfite conversion-dependent methods, restriction enzymedependent methods and affinity enrichment-dependent methods.

\section{Bisulfite Conversion-Dependent Methods}

Sodium bisulfite conversion is the most widely used method to distinguish unmethylated cytosines from methylated ones, and can be coupled with various downstream detection technologies, for example, microarrays, next-generation sequencing (NGS), PCR-based assays, pyrosequencing, quantitative methylation-specific polymerase chain reaction (qMSP) and whole-genome shotgun bisulfite sequencing (WGSBS). Sodium bisulfite rapidly deaminates unmethylated cytosines to uracils, whereas methylated cytosines are only slowly converted [62]. However, bisulfite treatment can induce random DNA breaks, resulting in short single-stranded DNA fragments, especially for cfDNA that is sparse and highly fragmented. Several bisulfite conversion kits with improved recovery of cfDNA have become commercially available, mainly through reducing the incubation time of DNA with bisulfite conversion reagent [63, 64]. Bisulfite treatment also induces reduction in sequence complexity, and cannot distinguish 5-methylcytosines from 5-hydroxymethylcitosines [65], both resulting in compromising efficiency.

\section{Restriction Enzyme-Dependent Methods}

Restriction enzyme-dependent method utilizes methylationsensitive restriction enzymes (MSREs) that solely cut unmethylated DNA, so that the rate of false-positives due to incomplete DNA digestion can be prevented. MSREs can be coupled with some downstream detection technologies, for example, differential methylation hybridization $(\mathrm{DMH}), \mathrm{MCA}$ with microarray hybridization 
(MCAM), HpaII tiny fragment enrichment by ligationmediated PCR (HELP), combined bisulfite restriction analysis (COBRA) and methylation-specific multiplex ligation-dependent probe amplification (MS-MLPA). The disadvantage of this method is only a particular pattern of CpG sites can be analyzed.

\section{Affinity Enrichment-Dependent Methods}

Affinity enrichment-dependent methods utilize specific antibodies interacted with methylated cytosine or methyl-binding proteins to enrich methylated DNA, before further examination with whole-genome analysis by array-based hybridization or next generation sequencing as well as gene-specific determination by PCR. Examples include MethylCpG Binding Domain MBD2 proteins (MBD, also termed Methyl Cap), methylated DNA immunoprecipitation (MeDIP) and methylated $\mathrm{CpG}$ island recovery assay (MIRA) [66]. Low recovery rate of methylated DNA is the main disadvantage [67-69].

\section{Smoking and Lung-Cancer-Related DNA Methylation from Liquid Biopsy}

Various factors associated with lung cancer have been shown to alter epigenome that is lung-cancer related, for example aging, chronic inflammation and cigarette smoking [70, 71]. Russo AL et al. report hypermethylation at ECAD, p16, MGMT and DAPK from peripheral lymphocytes DNA as smoking specific epigenome alternation [53]. Baglietto $\mathrm{L}$ et al. identified $6 \mathrm{CpGs}$ hypomethylation in 5 genes (AHRR, F2RL3, 2q37.1, 6p21.33 and 12q14.1) from peripheral blood related to smoking that may raise lung cancer risk, and 5 of them were lowest for current smokers and increased with time since quitting for former smokers. Methylation at these $6 \mathrm{CpGs}$ can help improving prediction of lung cancer risk [72]. Gao X et al. demonstrated the impact of tobacco smoking on DNA methylation at 8 lung-cancer-related genes (KLF6, STK32A, TERT, MSH5, ACTA2, GATA3, VTI1A and CHRNA5). DNA hypomethylation in 11 loci was linked to current smokers, compared with never smokers and 10 of them showed significant associations with life-time cumulative smoking [73]. Interestingly, a study from Davis A et al. does not support the association between global blood DNA methylation and the risk of lung cancer in non-smoking women [74], and supports the association between smoking, DNA methylation and lung cancer from opposite side. These studies demonstrate the role of smoking in promoting lung cancer through DNA methylation.

\section{Methylated DNA from Liquid Biopsy as Biomarkers for Lung Cancer}

Tumor-specific methylation of ctDNA are promising biomarkers to help screening, diagnosis, prognosis, monitoring and prediction of therapy response. Due to relatively low efficiency of single biomarker, it is more common to use combination of ctDNA methylations to improve sensitivity and specificity. Some researchers explored the potential role of DNA methylation as a target for lung cancer treatment. Methylated DNA can also be acquired from csbDNA [49, 50], buffy coat DNA [51], and blood cell [75] including lymphocyte $[52,53]$ and leukocyte [54, 55]. DNA methylations from EBC [57] and sputum [56] are also reported to be associated with lung cancer diagnosis and prognosis.

\section{Screening and Diagnosis}

Methylation occurs at early stage of carcinogenesis, and has become an attractive biomarker for cancer screening and early detection, especially for ctDNA methylation with its convenience and non-invasion. Many studies have reported the potential of ctDNA methylations for the screening and diagnosis of lung cancer. Various gene promoter methylations (Table 1) and their combinations (Table 2) were found to be effective in discriminating lung cancer patients from non-cancer controls. Biomarkers mostly investigated include SHOX2 [46, 47, 76, 77], RASSF1A [54, 75, 78-80], RARB2 [50, 78], LINE-1 [49, 51], P16 [54, 57, 81-83], MGMT [53, 79, 81], DAPK $[53,56,81]$, APC $[47,79,84]$ and DLEC1 $[47,85]$. For example, Powrózek T et al. evaluated DCLK1 methylation status in DNA isolated from peripheral blood plasma from 65 lung cancer patients and 95 healthy individuals. DCLK1 promoter methylation was detected in 32 lung cancer patients (49.2\%) and 8 healthy individuals (8.4\%). The methylation of the region before transcription start site (TSS) and the region after TSS of DCLK1 gene was detected in 28 and 11 patients, respectively. In seven cases $(10.8 \%)$, the DCLK1 promoter methylation in both regions was reported. The methylation was observed slightly frequent in patients with small cell lung cancer [17]. Weiss $\mathrm{G}$ et al. examined 330 plasma specimens in three independent case-control studies, resulting in a panel of SHOX2 and PTGER4 to distinguish lung cancer from control (area under the receiver operating characteristic curve $=91-98 \%$ ). A validation study with 172 patient samples demonstrated good performance in distinguishing LC patients from subjects without malignancy (area under the curve $=0.88)$ [77].

A large proportion of results mentioned above are based on studies comparing advanced lung cancer with healthy control. To avoid bias and improve the screening and early diagnosis efficiency, studies should include specifically early stage LC and non-cancer control.

\section{Monitoring and Prognosis}

DNA methylation can be used to indicate risk of cancer recurrence due to residual disease after surgery/ 
Table 1 Single DNA methylation from liquid biopsy as Biomarkers for lung cancer diagnosis

\begin{tabular}{|c|c|c|c|c|c|c|}
\hline DNA methylation & Body fluid & Method & $\begin{array}{l}\text { Number } \\
\text { of cases }\end{array}$ & $\begin{array}{l}\text { Number of } \\
\text { controls }\end{array}$ & $\begin{array}{l}\text { Sensitivity (\%)/specificity } \\
(\%) \text { or main findings }\end{array}$ & References \\
\hline \multirow[t]{2}{*}{$\overline{\mathrm{SHOX} 2}$} & plasma & qMSP & 222 & 189 & $60 / 90$ & [76] \\
\hline & plasma & qMSP & 38 & 31 & $80.65 / 78.57$ & [46] \\
\hline DCLK1 & plasma & qMSP & 65 & 95 & $49.2 / 91.6$ & [17] \\
\hline SEPT9 & plasma & qMSP & 75 & 100 & $44.3 / 92.3$ & [106] \\
\hline IEAA & blood & HM450K & 43 & 1986 & $\begin{array}{l}\text { one unit increase in IEAA was } \\
\text { associated with } 50 \% \text { higher risk } \\
\text { for LC }\end{array}$ & [107] \\
\hline \multirow[t]{2}{*}{ RARß2 } & plasma & MSP & 52 & 26 & $63 / 51$ & [50] \\
\hline & csbDNA & MSP & 52 & 26 & $70 / 63$ & [50] \\
\hline DLEC1 & plasma & MSP & 78 & 50 & $36 / 98$ & [85] \\
\hline $\mathrm{CDH} 1$ & serum & qMSP & 76 & 30 & $62 / 70$ & [79] \\
\hline DCC & serum & qMSP & 76 & 30 & $35.5 / 100$ & [79] \\
\hline $\mathrm{CDH} 13$ & plasma & MSP & 63 & 36 & $33 / 83$ & [108] \\
\hline \multirow[t]{5}{*}{ P16 } & serum & MSP & 22 & 0 & $14 \%$ & [81] \\
\hline & plasma & F-MSP & 35 & 15 & $40 / 100$ & [82] \\
\hline & plasma & modified semi-nested MSP & 105 & 0 & $73 \%$ & [83] \\
\hline & Plasma & F-MSP & 30 & 30 & $50 \%$ & {$[57]$} \\
\hline & EBC & F-MSP & 30 & 30 & $40 \%$ & {$[57]$} \\
\hline \multirow[t]{2}{*}{ DAPK } & serum & MSP & 22 & 0 & $18 \%$ & [81] \\
\hline & serum & NA & 50 & 0 & $40 \%$ & [80] \\
\hline GSTP1 & serum & MSP & 22 & 0 & $5 \%$ & [81] \\
\hline MGMT & serum & MSP & 22 & 0 & $18 \%$ & [81] \\
\hline TMS1 & serum & NA & 50 & 0 & $34 \%$ & {$[80]$} \\
\hline \multirow[t]{2}{*}{ RASSFS1A } & serum & NA & 50 & 0 & $34 \%$ & [80] \\
\hline & blood cell & NA & NA & NA & positive with LC diagnosis. & [75] \\
\hline APC & Serum/plasma & MSP & 89 & 50 & $47 \%$ & {$[84]$} \\
\hline \multirow[t]{2}{*}{ LINE-1 } & csbDNA & MIRA & 56 & 44 & AUC0.69 & [49] \\
\hline & Buffy coat DNA & PCR pyrosequencing & 34 & 360 & $\begin{array}{l}\text { Hypomethylation is associated } \\
\text { with 3.2-fold higher risk for LC }\end{array}$ & {$[51]$} \\
\hline p53 & peripheral lymphocyte DNA & Hpall quantitative PCR & 100 & - & $\begin{array}{l}\text { Hypomethylation was associated } \\
\text { with a 2-fold increased risk for LC }\end{array}$ & {$[52]$} \\
\hline
\end{tabular}

qMSP quantitative methylation-specific $\mathrm{PCR}, F-M S P$ fluorescent methylation-specific $\mathrm{PCR}, H M 450 \mathrm{~K}$ HumanMethylation450K BeadChip Assay, MSP methylation-specific PCR, MIRA methylated CpG island recovery assay, LC lung cancer, SHOX2 short stature homebox 2, DCLK1 doublecortin like kinase 1, SEPT9 septin9, IEAA intrinsic epigenetic age acceleration, $R A R \beta 2$ retinoic acid receptor $B 2, D L E C 1$ Deleted in lung and esophageal cancer 1, $C D H 1$ cadherin 1, DCC DCC netrin 1 receptor, $C D H 13$ cadherin 13, DAPK death-associated protein kinase, GSTP1 glutathione S-transferase P1, MGMT O6 - methylguanine-DNA-methyltransferase, RASSF1A ras association domain family 1 isoform A, APC adenomatous polyposis coli, p16 cyclin-dependent kinase inhibitor 2A, csbDNA cell-surface-bound circulating DNA, EBC exhaled breath condensate, NA not available

chemotherapy. Due to its short half-life, ctDNA can reflect tumor burden sensitively and allows 'real-time' monitoring of tumor dynamics. Persistence of ctDNA in blood after surgery is associated with poor prognosis [39]. In early stage like stage Ib NSCLC, benefit from adjuvant chemotherapy is controversial, and ctDNA methylation might be used as a prognostic biomarker to define patients at high risk of recurrence who may benefit from chemotherapy. In patients with high probability of recurrence after surgery, monitoring with ctDNA methylation can be a good surrogate to image and tumor markers, and improve clinical outcome with early detection of recurrence $[45,86]$. Ponomaryova $\mathrm{AA}$ et al. investigated the methylation status in plasma of 32 healthy donors and 60 lung cancer patients before and after treatment, and found that chemotherapy and total tumor resection resulted in a significant decrease in the index of methylation for RARB2 and RASSF1A, and methylation of RARB2 detected within follow-up period manifested disease relapse at 9 months [78]. Schmidt B et al. demonstrated better survival in patients with low SHOX2 promotor methylation 1 week after the start of chemotherapy [87]. In 
Table 2 Combination of DNA methylation from liquid biopsy as Biomarkers for lung cancer diagnosis

\begin{tabular}{|c|c|c|c|c|c|c|}
\hline DNA methylation combination & Body fluid & Method & $\begin{array}{l}\text { Number } \\
\text { of cases }\end{array}$ & $\begin{array}{l}\text { Number of } \\
\text { controls }\end{array}$ & $\begin{array}{l}\text { Sensitivity } \% / \text { specificity } \% \\
\text { or main findings }\end{array}$ & References \\
\hline RASSF1A/RARB2 & Plasma/csbDNA & qMSP & 60 & 32 & $87 / 75$ & {$[78]$} \\
\hline SHOX2/PTGER4 & plasma & Rt-PCR & 117 & 122 & $67 / 90$ or $90 / 73$ & {$[77]$} \\
\hline RTEL1/PCDHGB6 & cfDNA & qMSP-PCR & 70 & 80 & 62.9/90 (AUC0.755) & {$[17]$} \\
\hline HOXD10/PAX9/PTPRN2/STAG3 & serum & MSRE/qPCR & 23 & 23 & $87.8 / 90.2$ & [109] \\
\hline APC/RASSF1A/CDH13/KLK1/DLEC1 & plasma & MSP & 110 & 50 & $83 / 70$ & {$[47]$} \\
\hline $\begin{array}{l}\text { APC/AIM1/CDH1/DCC/MGMT/ } \\
\text { RASSF1A }\end{array}$ & serum & qMSP & 76 & 30 & $84 / 57$ & [79] \\
\hline $\begin{array}{l}\text { DAPK/PAX5b/PAX5a/Dal1/GATA5/ } \\
\text { SULF2/CXCL14 }\end{array}$ & sputum & MSP & 40 & 90 & $75 / 68$ & {$[56]$} \\
\hline $\begin{array}{l}\text { MGMT/DAPK/PAX5ß/Dal-1/PCDH20/ } \\
\text { Jph3/Kif1a }\end{array}$ & & & 64 & 64 & & \\
\hline CSF3R/ERCC1 & $\begin{array}{l}\text { peripheral } \\
\text { leukocyte }\end{array}$ & pyrosequencing & 138 & 138 & $\begin{array}{l}\text { Predict higher risk for } \\
\text { SCLC }\end{array}$ & [55] \\
\hline \multirow[t]{2}{*}{ CDH1/p16/MGMT/DAPK } & \multirow[t]{2}{*}{$\begin{array}{l}\text { peripheral } \\
\text { lymphocyte }\end{array}$} & \multirow[t]{2}{*}{ MSP } & \multirow[t]{2}{*}{49} & \multirow[t]{2}{*}{22} & $\begin{array}{l}\text { methylation of } \mathrm{CDH} 1 \text { and } \\
\text { DAPK occurs in the early } \\
\text { stages LC }\end{array}$ & \multirow[t]{2}{*}[53]{} \\
\hline & & & & & $\begin{array}{l}\text { methylation of p16 and } \\
\text { MGMT occurs in later } \\
\text { stages LC }\end{array}$ & \\
\hline p16/RASSF1A/FHIT/RTL & WBC DNA & $\begin{array}{l}\text { SYBR Green-based qMSP } \\
\text { and qPCR }\end{array}$ & 200 & 200 & AUC $0.670-0.810$ & [54] \\
\hline \multicolumn{7}{|c|}{ 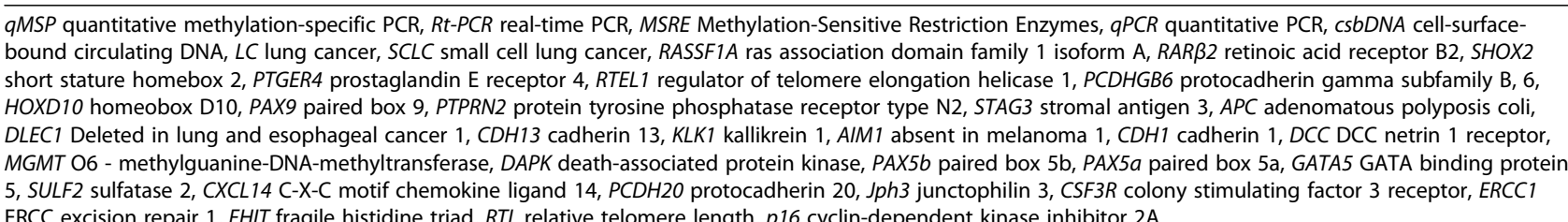 } \\
\hline
\end{tabular}

Table 3 Methylation of DNA from liquid biopsy as biomarkers for lung cancer prognosis and prediction

\begin{tabular}{|c|c|c|c|c|c|c|}
\hline DNA methylation & Body fluid & Method & $\begin{array}{l}\text { Number } \\
\text { of cases }\end{array}$ & $\begin{array}{l}\text { Number of } \\
\text { controls }\end{array}$ & Main findings & $\overline{\text { References }}$ \\
\hline $\mathrm{SHOX} 2$ & plasma & qMSP & 36 & - & negative impact on survival & {$[87]$} \\
\hline RARB2/RASSF1A & plasma & qMSP & 26 & - & $\begin{array}{l}\text { Reduced after neoadjuvant chemotherapy } \\
\text { and surgery; }\end{array}$ & [78] \\
\hline RARB2 & plasma & qMSP & 26 & - & increased before recurrence & [78] \\
\hline RASSF1A/APC & plasma & qMSP & 316 & - & $\begin{array}{l}\text { Elevated after chemotherapy; correlated with } \\
\text { good response to cisplatin }\end{array}$ & [89] \\
\hline DCLK1 & plasma & qMSP & 65 & 95 & negative impact on survival & {$[17]$} \\
\hline BRMS1 & plasma & qMSP & 122 & 24 & negative impact on survival & [86] \\
\hline SOX17 & plasma & qMSP & 122 & 24 & negative impact on survival & [45] \\
\hline SFN & serum & qMSP & 115 & - & $\begin{array}{l}\text { positive impact on survival with platinum-based } \\
\text { chemotherapy }\end{array}$ & {$[88]$} \\
\hline CHFR & serum & qMSP & 366 & - & $\begin{array}{l}\text { negative impact on survival with second-line } \\
\text { EGFR-TKIs, compared to chemotherapy }\end{array}$ & {$[90]$} \\
\hline smoCpGs & $\begin{array}{l}\text { Whole } \\
\text { blood }\end{array}$ & HM450K & 60 & 1505 & predict LC mortality (HR7.82) & [110] \\
\hline $\begin{array}{l}\text { APC/RASSF1A/CDH13/ } \\
\text { CDKN2A }\end{array}$ & Plasma & MSP & 45 & - & negative impact on PFS and OS & {$[31]$} \\
\hline
\end{tabular}


advanced and metastatic lung cancer, some biomarkers are associated with disease progression and survival, including BRMS1 [86], SOX17 [45], DCLK1 [17], and SFN (14-3-3 Sigma) promoter methylation [88] (Table 3).

\section{Prediction of Therapy Response}

ctDNA provides an potential detection of early response to treatment, compared with conventional imaging or protein based biomarkers. Several studies have reported the use of tumor-specific methylation to track patient's response to therapy (Table 3). For example, Wang $\mathrm{H}$ et al. reported an elevated level of APC and RASSF1A promoter methylation in ctDNA within $24 \mathrm{~h}$ after cisplatinbased therapy, consistent with chemotherapy induced cell death [89]. The value of methylated ctDNA to predict response to therapy has also been investigated. For example, Salazar F et al. reported that patients with unmethylated CHFR promoter survived longer when receiving EGFR tyrosine kinase inhibitors as second-line treatment, compared to conventional chemotherapy [90].

\section{Target for Therapy}

With the significance of DNA methylation in cancer progression, epigenetic treatment became a potential therapeutic candidate. Effect of epigenetic therapy in lung cancer has been reported. Juergens RA et al. investigated combined epigenetic therapy with azacitidine and entinostat, inhibitors of DNA methylation and histone deacetylation respectively, in patients with recurrent metastatic NSCLC, and with demethylation of a set of 4 epigenetically silenced genes known to be associated with lung cancer in serial blood samples, resulted in objective and durable responses [31]. Further investigations of methylated ctDNA as a treatment target are expected.

\section{Emerging Role of RNA Methylation}

RNA methylation was first described as a form of post-transcriptional modification more than 40 years ago [91, 92]. But the exact mechanism and significance of methylated RNA is just beginning to be appreciated. Among more than a hundred types of nucleotide modifications identified in different RNA molecules [93, 94], m6A modification has attracted most attention owing to its potential to regulate gene expression reversibly. RNA with m6A modification does not activate TLR3 [95, 96], leading to non-recognition of viral components, and may stimulate a pathway involved in cancer development [96-98]. RNA methylation may alter miRNA expression and mediate cancer cell migration [99]. RNA methylation may be involved in cancer stem cells specification and disease progression [100]. The application of circulating RNA methylation in various types of cancer has been reported. For example, Muraoka T et al. proved that serum miR-34b/c methylation can be used for the diagnosis and prognosis of malignant pleural mesothelioma [101]. Drugs that induced RNA demethylation might contribute to patient responses [102, 103]. Lian CG et al. reported another type of modification in RNA, 5hydroxymethyl cytosine $(5 \mathrm{hmC})$, as a signature for melanoma prognosis [104]. Further research on circulating RNA methylation in lung cancer is anticipated.

\section{Conclusions and Perspectives}

Lung cancer liquid biopsy has received increasing attention in recent years with its advantage as a non-invasive detection. Among the huge amount of information obtained from liquid biopsy, epigenetic alterations, especially DNA/ RNA methylation, has been widely researched. ctDNA/ RNA methylation has been associated with the screening, diagnosis, prognosis, monitoring and treatment prediction of lung cancer. The advances in techniques enable detection of methylation from sparse and fragmented DNA/ RNA. For example, it is now feasible to detect DNA/RNA methylation from single CTC [105]. However, the methodology is still in lack of standardization, which hinders the development of methylation studies in every aspect. It is urgent to establish standardized protocols from sample storage, ctDNA/RNA extraction to methylation analysis. Translating circulating epigenetic biomarkers from clinical study to clinical routine for lung cancer is expected.

\section{Abbreviations}

AIM1: Absent in melanoma 1; APC: Adenomatous polyposis coli; BRMS1: Breast cancer metastasis suppressor-1; caCpGs: Lung cancer-related CpGs; CDH1: Cadherin 1; CDH13: Cadherin 13; CDKN2A: Cyclin dependent kinase inhibitor 2A; cfDNA: Circulating cell-free DNA; CGIs: CpG islands; CHFR: Checkpoint with forkhead and ring finger domains; COBRA: Combined Bisulfite Restriction Analysis; csbDNA: Cell-surface-bound circulating DNA; CSF3R: Colony stimulating factor 3 receptor; CTCs: Circulating tumor cells; CtDNA: Circulating tumor DNA; CXCL14: C-X-C motif chemokine ligand 14; DAPK: Death-associated protein kinase; DCC: DCC netrin 1 receptor; DCLK1: Doublecortin like kinase 1; DLEC1: Deleted in lung and esophageal cancer 1; DMH: Differential methylation hybridization; EBC: Exhaled breath condensate; ERCC1: ERCC excision repair 1; FHIT: Fragile histidine triad; FMSP: Fluorescent methylation-specific PCR; GATA5: GATA binding protein 5; GSTP1: Glutathione S-transferase P1; HELP: Hpall tiny fragment enrichment by ligation-mediated PCR; HM450K: HumanMethylation450K BeadChip Assay; HOXD10: Homeobox D10; IEAA: Intrinsic epigenetic age acceleration; Jph3: Junctophilin 3; KLK1: Kallikrein 1; LC: Lung cancer; LDCT: Low-dose computed tomography; MBD: MethylCpG Binding Domain MBD2 proteins; MCAM: MCA with microarray hybridization; MeDIP: Methylated DNA immunoprecipitation; MGMT: O6 - methylguanine-DNA-methyltransferase; MIRA: Methylated CpG island recovery assay; MS-MLPA: Methylation-specific multiplex ligation-dependent probe amplification; MSP: Methylation-specific PCR; MSREs: Methylation-Sensitive Restriction Enzymes; NA: Not available; NGS: Next-generation sequencing; OS: Overall survival; p16: Cyclindependent kinase inhibitor 2A; PAX5a: Paired box 5a; PAX5b: Paired box 5b; PAX9: Paired box 9; PCDH20: Protocadherin 20; PCDHGB6: Protocadherin gamma subfamily B, 6; PFS: Progression free survival; PTGER4: Prostaglandin E receptor 4; PTPRN2: Protein tyrosine phosphatase receptor type N2; GMSP: Quantitative methylation-specific polymerase chain reaction; QPCR: Quantitative PCR; RARß2: Retinoic acid receptor B2; RASSF1A: Ras association domain family 1 isoform A; RTEL1: Regulator of telomere elongation helicase 1; RTL: Relative telomere length; SCLC: Small cell lung cancer; SEPT9: Septin9; SFN: Stratifin; SHOX2: Short stature homebox 2; smoCpGs: Smoking-associated CpGs; SOX17: (sex determining region Y)-box 
17; STAG3: Stromal antigen 3; SULF2: Sulfatase 2; TSS: Transcription start site; WGSBS: Whole-genome shotgun bisulfite sequencing

\section{Acknowledgements}

Yao Yaxian helped with providing full-text download.

\section{Funding}

funded by Science and Technology Commission of Shanghai Municipality, key projects of traditional chinese medicine (16401970700). The funding body has no role in the design of the study and collection, analysis and interpretation of data and in writing the manuscript.

\section{Availability of Data and Materials}

All data in this review is from publications found on pubmed.

\section{Authors' Contribution}

LY, LS and XL chose this subject and made outlines. LY searched database, collected datas and wrote the manuscript. ZS, GY and SJ helped with data collection and analysis, and provided valuable opinions on the writing of the manuscript. All authors read and approved the final manuscript.

\section{Competing Interests}

The authors declare that they have no competing interests.

\section{Consent for Publication}

Not applicable.

\section{Ethics Approval and Consent to Participate}

Not applicable.

\section{Author details}

${ }^{1}$ No.2 oncology department, Yueyang Hospital of Integrated Traditional Chinese and Western Medicine, Shanghai University of Traditional Chinese Medicine, No.110, Ganhe Rd, Shanghai, China. ' ${ }^{2}$ DD Anderson Cancer Center, the university of Texas, 1840 Old Spanish Trail, Houston, TX, USA.

${ }^{3}$ Department of Immunology and Pathogenic Biology, School of Basic Medical Sciences, Shanghai University of Traditional Chinese Medicine, 1200 Cai Lun Rd, Shanghai, China.

\section{Received: 4 February 2017 Accepted: 2 March 2017}

\section{Published online: 17 March 2017}

\section{References}

1. Siegel RL, Miller KD, Jemal A. Cancer Statistics, 2016. CA Cancer J Clin. 2016;66:7-30.

2. Secretan B, Straif K, Baan R, et al. A Review of Human Carcinogens-Part E: Tobacco, Areca Nut, Alcohol, Coal Smoke, and Salted Fish. Lancet Oncol. 2009;10:1033-4.

3. Team NLSTR, Aberle DR, Adams AM, et al. Reduced Lung-cancer Mortality with Low-dose Computed Tomographic Screening. N Engl J Med. 2011;365:395-409.

4. Patz Jr EF, Pinsky P, Gatsonis C, et al. Overdiagnosis in Low-dose Computed Tomography Screening for Lung Cancer. JAMA Intern Med. 2014;174:269-74.

5. Chansky K, Sculier JP, Crowley JJ, et al. The International Association for the Study of Lung Cancer Staging Project: Prognostic Factors and Pathologic TNM Stage in Surgically Managed Non-small Cell Lung Cancer. J Thorac Oncol. 2009:4:792-801.

6. Howlader N, Noone AM, Krapcho M, et al. SEER Cancer Statistics Review, 1975-2013, Based on November 2015 SEER Data Submission, Posted to the SEER Web Site, April 2016. Bethesda: National Cancer Institute; 2016. https://seer.cancer.gov/csr/1975_2013/. Accessed 3 Feb 2017.

7. Berger SL, Kouzarides T, Shiekhattar R, et al. An Operational Definition of Epigenetics. Genes Dev. 2009;23:781-3.

8. Sharma S, Kelly TK, Jones PA. Epigenetics in Cancer. Carcinogenesis. 2010;31:27-36

9. Baylin SB. The Cancer Epigenome: Its Origins, Contributions to Tumorigenesis, and Translational Implications. Proc Am Thorac Soc. 2012;9:64-5.

10. Baylin SB, Jones PA. Epigenetic Determinants of Cancer. Cold Spring Harb Perspect Biol. 2016;8:a019505

11. Bird A. DNA Methylation Patterns and Epigenetic Memory. Genes Dev. 2002;16:6-21.
12. Prendergast GC, Ziff EB. Methylation-sensitive Sequence-Specific DNA Binding by the c-Myc Basic Region. Science. 1991;251:186-9.

13. Watt F, Molloy PL. Cytosine Methylation Prevents Binding to DNA of a HeLa Cell Transcription Factor Required for Optimal Expression of the Adenovirus Major Late Promoter. Genes Dev. 1988;2:1136-43.

14. Nan $\mathrm{X}, \mathrm{Ng} \mathrm{HH}$, Johnson CA, et al. Transcriptional Repression by the MethylCpG-binding Protein MeCP2 Involves a Histone Deacetylase Complex. Nature. 1998;393:386-9.

15. Jones PL, Veenstra GJ, Wade PA, et al. Methylated DNA and MeCP2 Recruit Histone Deacetylase to Repress Transcription. Nat Genet. 1998;19:187-91.

16. Baylin SB, Jones PA. A Decade of Exploring the Cancer Epigenome Biological and Translational Implications. Nat Rev Cancer. 2011;11:726-34.

17. Powrózek T, Krawczyk P, Nicoś M, et al. Methylation of the DCLK1 Promoter Region in Circulating Free DNA and its Prognostic Value in Lung Cancer Patients. Clin Transl Oncol. 2016:18:398-404.

18. Tsou JA, Galler JS, Siegmund KD, et al. Identification of a Panel of Sensitive and Specific DNA Methylation Markers for Lung Adenocarcinoma. Mol Cancer. 2007;6:70

19. Kontic M, Stojsic J, Jovanovic D, et al. Aberrant Promoter Methylation of $\mathrm{CDH} 13$ and MGMT Genes is Associated with Clinicopathologic Characteristics of Primary Non-small-cell Lung Carcinoma. Clin Lung Cancer. 2012;13(4):297-303.

20. Sato T, Arai E, Kohno T, et al. Epigenetic Clustering of Lung Adenocarcinomas Based on DNA Methylation Profiles in Adjacent Lung Tissue: Its Correlation with Smoking History and Chronic Obstructive Pulmonary Disease. Int J Cancer. 2014;135:319-34.

21. Hawes SE, Stern JE, Feng Q, et al. DNA Hypermethylation of Tumors from Non-small Cell Lung Cancer (NSCLC) Patients is Associated with Gender and Histologic Type. Lung Cancer. 2010;69:172-9.

22. Carvalho $\mathrm{RH}$, Hou J, Haberle V, et al. Genomewide DNA Methylation Analysis Identifies Novel Methylated Genes in Non-small-cell Lung Carcinomas. J Thorac Oncol. 2013:8:562-73.

23. Walter $K$, Holcomb T, Januario T, et al. DNA Methylation Profiling Defines Clinically Relevant Biological Subsets of Non-small Cell Lung Cancer. Clin Cancer Res. 2012;18:2360-73.

24. Shinjo K, Okamoto $Y$, An B, et al. Integrated Analysis of Genetic and Epigenetic Alterations Reveals CpG Island Methylator Phenotype Associated with Distinct Clinical Characters of Lung Adenocarcinoma. Carcinogenesis. 2012;33:1277-85.

25. Cancer Genome Atlas Research Network. Comprehensive Molecular Profiling of Lung Adenocarcinoma. Nature. 2014;511:543-50.

26. Selamat SA, Galler JS, Joshi AD, et al. DNA Methylation Changes in Atypical Adenomatous Hyperplasia, Adenocarcinoma in Situ, and Lung Adenocarcinoma. PLoS One. 2011;6:e21443.

27. Brock MV, Hooker CM, Ota-Machida E, et al. DNA Methylation Markers and Early Recurrence in Stage I Lung Cancer. N Engl J Med. 2008;358:1118-28.

28. Sato T, Arai E, Kohno T, et al. DNA Methylation Profiles at Precancerous Stages Associated with Recurrence of Lung Adenocarcinoma. PLoS One. 2013:8.e59444

29. Sandoval J, Mendez-Gonzalez J, Nadal E, et al. A Prognostic DNA Methylation Signature for Stage I Nonsmall-cell Lung Cancer. J Clin Oncol. 2013;31:4140-7.

30. Robles Al, Arai E, Mathé EA, et al. An Integrated Prognostic Classifier for Stage I Lung Adenocarcinoma Based on mRNA, microRNA, and DNA Methylation Biomarkers. J Thorac Oncol. 2015;10:1037-48.

31. Juergens RA, Wrangle J, Vendetti FP, et al. Combination Epigenetic Therapy has Efficacy in Patients with Refractory Advanced Non-small Cell Lung Cancer. Cancer Discov. 2011;1(7):598-607.

32. Gama-Sosa MA, Slagel VA, Trewyn RW, et al. The 5-methylcytosine Content of DNA from Human Tumors. Nucleic Acids Res. 1983;11:6883-94.

33. Pfeifer GP, Rauch TA. DNA Methylation Patterns in Lung Carcinomas. Semin Cancer Biol. 2009:19:181-7.

34. Feinberg AP, Vogelstein B. Hypomethylation Distinguishes Genes of some Human Cancers from their Normal Counterparts. Nature. 1983:301:89-92.

35. Feinberg AP, Vogelstein B. Hypomethylation of Ras Oncogenes in Primary Human Cancers. Biochem Biophys Res Commun. 1983;111:47-54

36. Rauch TA, Zhong X, Wu X, et al. High-resolution Mapping of DNA Hypermethylation and Hypomethylation in Lung Cancer. Proc Nat Acad Sci U S A. 2008;105:252-7.

37. El Messaoudi S, Rolet F, Mouliere F, et al. Circulating Cell Free DNA: Preanalytical Considerations. Clin Chim Acta. 2013;424:222-30. 
38. Warton K, Lin V, Navin T, et al. Methylation-capture and Next-generation Sequencing of Free Circulating DNA from Human Plasma. BMC Genomics. 2014;15:476

39. Diehl F, Schmidt K, Choti MA, et al. Circulating Mutant DNA to Assess Tumor Dynamics. Nat Med. 2008;14:985-90.

40. Jahr S, Hentze H, Englisch S, et al. DNA Fragments in the Blood Plasma of Cancer Patients: Quantitations and Evidence for their Origin from Apoptotic and Necrotic Cells. Cancer Res. 2001;61:1659-65.

41. Fleischhacker M, Schmidt B. Circulating nucleic acids (CNAs) and cancer-a survey. Biochim Biophys Acta. 2007;1775:181-232.

42. Schwarzenbach $H$, Alix-Panabières $C$, Müller I, et al. Cell-free Tumor DNA in Blood Plasma as a Marker for Circulating Tumor Cells in Prostate Cancer. Clin Cancer Res. 2009;15:1032-8.

43. Shaw JA, Brown J, Coombes RC, et al. Circulating Tumor Cells and Plasma DNA Analysis in Patients with Indeterminate Early or Metastatic Breast Cancer. Biomark Med. 2011:5:87-91.

44. Thakur BK, Zhang H, Becker A, et al. Double-stranded DNA in Exosomes: A Novel Biomarker in Cancer Detection. Cell Res. 2014;24:766-9.

45. Balgkouranidou I, Chimonidou M, Milaki G, et al. SOX17 Promoter Methylation in Plasma Circulating Tumor DNA of Patients with Non-small Cell Lung Cancer. Clin Chem Lab Med. 2016;54:1385-93.

46. Konecny M, Markus J, Waczulikova I, et al. The Value of SHOX2 Methylation Test in Peripheral Blood Samples Used for the Differential Diagnosis of Lung Cancer and other Lung Disorders. Neoplasma. 2016;63:246-53.

47. Zhang $Y$, Wang $R$, Song $H$, et al. Methylation of Multiple Genes as a Candidate Biomarker in Non-small Cell Lung Cancer. Cancer Lett. 2011;303:21-8.

48. Margolin G, Petrykowska HM, Jameel N, et al. Robust Detection of DNA Hypermethylation of ZNF154 as a Pan-Cancer Locus with in Silico Modeling for Blood-based Diagnostic Development. J Mol Diagn. 2016;18:283-98.

49. Gainetdinov IV, Kapitskaya KY, Rykova EY, et al. Hypomethylation of Humanspecific Family of LINE-1 Retrotransposons in Circulating DNA of Lung Cancer Patients. Lung Cancer. 2016;99:127-30.

50. Ponomaryova AA, Rykova EY, Cherdyntseva NV, et al. RARß2 Gene Methylation Level in the Circulating DNA from Blood of Patients with Lung Cancer. Eur J Cancer Prev. 2011;20:453-5.

51. Zhu ZZ, Sparrow D, Hou L, et al. Repetitive Element Hypomethylation in Blood Leukocyte DNA and Cancer Incidence, Prevalence, and Mortality in Elderly Individuals: The Normative Aging Study. Cancer Causes Control. 2011;22:437-47

52. Woodson K, Mason J, Choi SW, et al. Hypomethylation of p53 in Peripheral Blood DNA is Associated with the Development of Lung Cancer. Cancer Epidemiol Biomarkers Prev. 2001;10:69-74.

53. Russo AL, Thiagalingam A, Pan H, et al. Differential DNA Hypermethylation of Critical Genes Mediates the Stage-specific Tobacco Smoke-induced Neoplastic Progression of Lung Cancer. Clin Cancer Res. 2005;11:2466-70.

54. Wang W, Feng X, Duan X, et al. Establishment of Two Data Mining Models of Lung Cancer Screening Based on Three Gene Promoter Methylations Combined with Telomere Damage. Int J Biol Markers. 2016;24:0.

55. Wang L, Aakre JA, Jiang R, et al. Methylation Markers for Small Cell Lung Cancer in Peripheral Blood Leukocyte DNA. J Thorac Oncol. 2010;5:778-85.

56. Leng S, Do K, Yingling CM, et al. Defining a Gene Promoter Methylation Signature in Sputum for Lung Cancer Risk Assessment. Clin Cancer Res. 2012;18:3387-95

57. Xiao P, Chen JR, Zhou F, et al. Methylation of P16 in Exhaled Breath Condensate for Diagnosis of Non-small Cell Lung Cancer. Lung Cancer. 2014:83:56-60

58. Lee TH, Montalvo L, Chrebtow V, et al. Quantitation of Genomic DNA in Plasma and Serum Samples: Higher Concentrations of Genomic DNA Found in Serum Than in Plasma. Transfusion. 2001;41:276-82.

59. Devonshire AS, Whale AS, Gutteridge A, et al. Towards Standardisation of Cell-free DNA Measurement in Plasma: Controls for Extraction Efficiency, Fragment Size Bias and Quantification. Anal Bioanal Chem. 2014;406:6499-512.

60. Mauger F, Dulary C, Daviaud C, et al. Comprehensive Evaluation of Methods to Isolate, Quantify, and Characterize Circulating Cell-free DNA from Small Volumes of Plasma. Anal Bioanal Chem. 2015;407:6873-8.

61. Page K, Guttery DS, Zahra N, et al. Influence of Plasma Processing on Recovery and Analysis of Circulating Nucleic Acids. PLoS One. 2013;8:e77963

62. Clark SJ, Harrison J, Paul CL, et al. High Sensitivity Mapping of Methylated Cytosines. Nucleic Acids Res. 1994;22:2990-7.
63. Hernández HG, Tse MY, Pang SC, et al. Optimizing Methodologies for PCR-based DNA Methylation Analysis. Biotechniques. 2013;55:181-97.

64. Holmes EE, Jung M, Meller S, et al. Performance Evaluation of Kits for Bisulfite-conversion of DNA from Tissues, Cell Lines, FFPE Tissues, Aspirates, Lavages, Effusions, Plasma, Serum, and Urine. PLoS One. 2014;9:e93933.

65. Hayatsu H, Shiragami M. Reaction of Bisulfite with the 5-hydroxymethyl Group in Pyrimidines and in Phage DNAs. Biochemistry. 1979;18:632-7.

66. Weber M, Davies JJ, Wittig D, et al. Chromosome-wide and Promoterspecific Analyses Identify Sites of Differential DNA Methylation in Normal and Transformed Human Cells. Nat Genet. 2005;37:853-62.

67. Jeuken JW, Cornelissen SJ, Vriezen M, et al. MS-MLPA: An Attractive Alternative Laboratory Assay for Robust, Reliable, and Semiquantitative Detection of MGMT Promoter Hypermethylation in Gliomas. Lab Invest. 2007:87:1055-65.

68. Huang ZH, Hu Y, Hua D, et al. Quantitative Analysis of Multiple Methylated Genes in Plasma for the Diagnosis and Prognosis of Hepatocellular Carcinoma. Exp Mol Pathol. 2011;91:702-7.

69. Sun FK, Fan YC, Zhao J, et al. Detection of TFPI2 Methylation in the Serum of Hepatocellular Carcinoma Patients. Dig Dis Sci. 2012;58:1010-5.

70. Liu F, Killian JK, Yang M, et al. Epigenomic Alterations and Gene Expression Profiles in Respiratory Epithelia Exposed to Cigarette Smoke Condensate. Oncogene. 2010:29:3650-64

71. Georgiadis P, Hebels DG, Valavanis I, et al. Omics for Prediction of Environmental Health Effects: Blood Leukocyte-based Cross-omic Profiling Reliably Predicts Diseases Associated with Tobacco Smoking. Sci Rep. 2016;6:20544

72. Baglietto L, Ponzi E, Haycock P, et al. DNA Methylation Changes Measured in Pre-diagnostic Peripheral Blood Samples are Associated with Smoking and Lung Cancer Risk. Int J Cancer. 2017;140:50-61.

73. Gao X, Zhang Y, Breitling LP, et al. Tobacco Smoking and Methylation of Genes Related to Lung Cancer Development. Oncotarget. 2016;7:59017-28.

74. Davis A, Tao MH, Chen J, et al. No association between global DNA methylation in peripheral blood and lung cancer risk in nonsmoking women: results from a multicenter study in Eastern and Central Europe. Eur J Cancer Prev. 2016. doi:10.1097/CEJ.0000000000000244.

75. Vineis $P$, Chuang SC, Vaissière T, et al. DNA Methylation Changes Associated with Cancer Risk Factors and Blood Levels of Vitamin Metabolites in a Prospective Study. Epigenetics. 2011;6:195-201.

76. Kneip C, Schmidt B, Seegebarth A, et al. SHOX2 DNA Methylation is a Biomarker for the Diagnosis of Lung Cancer in Plasma. J Thorac Oncol. 2011;6:1632-8.

77. Weiss $G$, Schlegel A, Kottwitz D, et al. Validation of the SHOX2/PTGER4 DNA Methylation Marker Panel for Plasma-Based Discrimination between Patients with Malignant and Nonmalignant Lung Disease. J Thorac Oncol. 2017;12(1):77-84.

78. Ponomaryova AA, Rykova EY, Cherdyntseva NV, et al. Potentialities of Aberrantly Methylated Circulating DNA for Diagnostics and Post-treatment Follow-up of Lung Cancer Patients. Lung Cancer. 2013;81:397-403.

79. Begum S, Brait M, Dasgupta S, et al. An Epigenetic Marker Panel for Detection of Lung Cancer Using Cell-free Serum DNA. Clin Cancer Res. 2011;17:4494-503.

80. Ramirez JL, Sarries C, de Castro PL, et al. Methylation Patterns and K-ras Mutationsin Tumor and Paired Serum of Resected Non-small Cell Lung Cancer Patients. Cancer Lett. 2003;193:207-16.

81. Esteller M, Sanchez-Cespedes M, Rosell R, et al. Detection of Aberrant Promoter Hypermethylation of Tumor Suppressor Genes in Serum DNA from Non-small Cell Lung Cancer Patients. Cancer Res. 1999;59:67-70.

82. Bearzatto A, Conte D, Frattini M, et al. p16(INK4A) Hypermethylation Detected by Fluorescent Methylation-specific PCR in Plasma from Nonsmall Cell Lung Cancer. Clin Cancer Res. 2002;8:3782-7.

83. An Q, Liu Y, Gao Y, et al. Detection of p16 Hypermethylation in Circulating Plasma DNA of Non-small Cell Lung Cancer Patients. Cancer Lett. 2002;188:109-14.

84. Usadel H, Brabender J, Danenberg KD, et al. Quantitative Adenomatouspolyposiscoli Promoter Methylation Analysis in Tumor Tissue, Serum, and Plasma DNA of Patients with Lung Cancer. Cancer Res. 2002;62:371-5.

85. Zhang Y, Miao Y, Yi J, et al. Frequent Epigenetic Inactivation of Deleted in Lung and Esophageal Cancer 1 Gene by Promoter Methylation in Nonsmall-cell Lung Cancer. Clin Lung Cancer. 2010;11:264-70.

86. Balgkouranidou I, Chimonidou M, Milaki G, et al. Breast Cancer Metastasis Suppressor-1 Promoter Methylation in Cell-free DNA Provides Prognostic Information in Nonsmall Cell Lung Cancer. Br J Cancer. 2014;110:2054-62.

87. Schmidt B, Beyer J, Dietrich D, et al. Quantification of Cell-free mSHOX2 Plasma DNA for Therapy Monitoring in Advanced Stage Non-small Cell (NSCLC) and Small-cell Lung Cancer (SCLC) Patients. PLoS One. 2015;10:e0118195. 
88. Ramirez JL, Rosell R, Taron M, et al. 14-3-3sigma Methylation in Pretreatment Serum Circulating DNA of Cisplatin-plus-gemcitabine-treated Advanced Nonsmallcell Lung Cancer Patients Predicts Survival: The Spanish Lung Cancer Group. J Clin Oncol. 2005;23:9105-12.

89. Wang $H$, Zhang $B$, Chen $D$, et al. Real-time Monitoring Efficiency and Toxicity of Chemotherapy in Patients with Advanced Lung Cancer. Clin Epigenetics. 2015;7:119.

90. Salazar F, Molina MA, Sanchez-Ronco M, et al. Firstline Therapy and Methylation Status of CHFR in Serum Influence Outcome to Chemotherapy Versus EGFR Tyrosine Kinase Inhibitors as Second-line Therapy in Stage IV Non-small-cell Lung Cancer Patients. Lung Cancer. 2011;72:84-91.

91. Desrosiers R, Friderici K, Rottman F. Identification of Methylated Nucleosides in Messenger RNA from Novikoff Hepatoma Cells. Proc Natl Acad Sci U S A. 1974;71:3971-5.

92. Rottman F, Shatkin AJ, Perry RP. Sequences Containing Methylated Nucleotides at the 5' Termini of Messenger RNAs: Possible Implications for Processing. Cell. 1974:3:197-9.

93. Kellner S, Burhenne J, Helm M. Detection of RNA Modifications. RNA Biol. 2010:7:237-47.

94. Behm-Ansmant I, Helm M, Motorin Y. Use of Specific Chemical Reagents for Detection of Modified Nucleotides in RNA. J Nucleic Acids. 2011;2011: 408053

95. Kariko K, Buckstein M, Ni H, et al. Suppression of RNA Recognition by Tolllike Receptors: The Impact of Nucleoside Modification and the Evolutionary Origin of RNA. Immunity. 2005;23:165-75.

96. So EY, Ouchi T. The Application of Toll Like Receptors for Cancer Therapy. IntJ Biol Sci. 2010;6:675-81.

97. Zhou Q, Zhu K, Cheng H. Toll-like Receptors in Human Papillomavirus Infection. Arch Immunol Ther Exp (Warsz). 2013;61:203-15.

98. Shcheblyakov DV, Logunov DY, Tukhvatulin Al, et al. Toll-like Receptors (TLRs): the Role in Tumor Progression. Acta Nat. 2010;2:21-9.

99. Yang L, Ma YM, Han WX, et al. Proteinase-activated Receptor 2 Promotes Cancer Cell Migration Through RNA Methylation-mediated Repression of miR-125b. J Biol Chem. 2015;290:26627-37.

100. Zhang C, Zhi WI, Lu H, et al. Hypoxia-Inducible Factors Regulate Pluripotency Factor Expression by ZNF217- and ALKBH5-mediated Modulation of RNA Methylation in Breast Cancer Cells. Oncotarget. 2016;7:64527-42.

101. Muraoka T, Soh J, Toyooka S, et al. The Degree of MicroRNA-34b/c Methylation in Serum-circulating DNA is Associated with Malignant Pleural Mesothelioma. Lung Cancer. 2013;82:485-90.

102. Schaefer M, Hagemann $S$, Hanna K, et al. Azacytidine Inhibits RNA Methylation at DNMT2 Target Sites in Human Cancer Cell Lines. Cancer Res. 2009;69:8127-32.

103. Moudra A, Hubackova S, Machalova V, et al. Dynamic Alterations of Bone Marrow Cytokine Landscape of Myelodysplastic Syndromes Patients Treated with 5-azacytidine. Oncoimmunology. 2016;5:e1183860.

104. Lian CG, Xu Y, Ceol C, et al. Loss of 5-hydroxymethylcytosine is an Epigenetic Hallmark of Melanoma. Cell. 2012;150:1135-46.

105. Huang W, Qi CB, Lv SW, et al. Determination of DNA and RNA Methylation in Circulating Tumor Cells by Mass Spectrometry. Anal Chem. 2016;88:1378-84.

106. Powrózek T, Krawczyk P, Kucharczyk T, et al. Septin 9 Promoter Region Methylation in Free Circulating DNApotential Role in Noninvasive Diagnosis of Lung Cancer: Preliminary Report. Med Oncol. 2014;31:917.

107. Levine ME, Hosgood HD, Chen B, et al. DNA Methylation Age of Blood Predicts Future Onset of Lung Cancer in the Women's Health Initiative. Aging (Albany NY). 2015;7:690-700.

108. Hsu HS, Chen TP, Hung C, et al. Characterization of a Multiple Epigenetic Marker Panel for Lung Cancer Detection and Risk Assessment in Plasma. Cancer. 2007;110:2019-26.

109. Matthias W, Klemens V, Ulrike $K$, et al. Diagnostic Performance of Plasma DNA Methylation Profiles in Lung Cancer, Pulmonary Fibrosis and COPD. EBioMedicine. 2015:2:929-36.

110. Zhang Y, Breitling LP, Balavarca Y, et al. Comparison and Combination of Blood DNA Methylation at Smoking-associated Genes and at Lung Cancerrelated Genes in Prediction of Lung Cancer Mortality. Int J Cancer. 2016;139: 2482-92.

\section{Submit your next manuscript to BioMed Central and we will help you at every step:}

- We accept pre-submission inquiries

- Our selector tool helps you to find the most relevant journal

- We provide round the clock customer support

- Convenient online submission

- Thorough peer review

- Inclusion in PubMed and all major indexing services

- Maximum visibility for your research

Submit your manuscript at www.biomedcentral.com/submit

) Biomed Central 